\title{
Peralihan Sistem Mata Pencaharian Dan Pola Interaksi Masyarakat Petani Kratom Di Kecamatan Putussibau Utara Kabupaten Kapuas Hulu Kalimantan Barat
}

\author{
Hot Jungjungan Simamora \\ Badan Pengembangan Sumber Daya Manusia, Provinsi Kalimantan Barat, Indonesia \\ Korespondensi* : morajungnakerkalbar@yahoo.com
}

\begin{abstract}
ABSTRAK
Penelitian ini dilakukan untuk mengetahui faktor-faktor yang mempengaruhi peralihan sistem mata pencaharian masyarakat Putussibau Utara setelah adanya pasar kratom. Penelitian ini dilakukan di Desa Banua Tengah, Desa Sungai Uluk Palin, dan Desa Hilir Kantor, Kecamatan Putussibau Utara, Kabupaten Kapuas Hulu, Pontianak. Lokasi penelitian dipilih secara sengaja dengan pertimbangan bahwa di Desa sampel terdapat masyarakat asli yang telah membudidayakan kratom minimal 2 tahun. Informan dalam penelitian ini adalah tokoh masyarakat, kepala desa, petani kratom, dan pemerintah desa. Data penelitian ini dianalisis dengan menggunakan model interaktif yang terdiri dari tiga alur kegiatan yang terjadi secara bersamaan yaitu : reduksi data, penyajian data, dan penarikan kesimpulan/verifikasi. Hasil penelitian menunjukkan bahwa terjadi peralihan sistem mata pencaharian dimana ditandai masyarakat asli mulai melakukan budidaya kratom bersama dengan tanaman budidaya yang sebelumnya udah ada. Peralihan sistem mata pencaharian ini dipengaruhi oleh tiga faktor, yaitu : kebijakan pemerintah, interaksi dengan warga desa, dan norma atau aturan yang mempengaruhi masyarakat asli Putussibau Utara dalam pemanfaatan lahan dan pengambilan sumber daya.
\end{abstract}

Kata Kunci: Peralihan, Kratom, Putussibau Utara

\section{ABSTRACT}

This research was conducted to determine the factors that influence the change in the livelihood system of the North Putussibau community after the kratom market. This research was conducted in Banua Tengah Village, Sungai Uluk Palin Village, and Hilir Kantor Village, Putussibau Utara District, Kapuas Hulu Regency, Pontianak. The research location was chosen deliberately with the consideration that in the sample village there were indigenous people who had cultivated kratom for at least 2 years. Informants in this study were community leaders, village heads, kratom farmers, and village government. The data of this study were analyzed using an interactive model consisting of three activities that occurred simultaneously, namely: data reduction, data presentation, and drawing conclusions / verification. The results showed that there was a shift in the livelihood system where indigenous peoples were marked to begin to cultivate kratom along with previously existing cultivation plants. The transition to this livelihood system is influenced by three factors, namely: government policies, interactions with villagers, and norms or rules that affect indigenous people of North Putussibau in land use and resource extraction.

Keywords: Transitional, Kratom, North Putussibau 


\section{PENDAHULUAN}

Putussibau Utara merupakan salah satu kecamatan di Kabupaten Kapuas Hulu yang berperan penting sebagai pemasok kratom yang diperdagangkan secara Internasional. Kratom (Mitragyna speciosa) merupakan kelompok tanaman berkayu yang termasuk famili kopi, dan tersebar luas di Asia Tenggara (USDA, 2013). Tanaman ini diketahui mengandung senyawa bioaktif potensial golongan alkaloid yaitu Mitragynine dan 7-hydroxymitragynine (7HMG) serta 40 senyawa lainnya yang berpotensi sebagai opioid dan penghilang rasa sakit (Warner, et al., 2016). Potensi senyawa bioaktif kratom inilah yang membuat kratom mempunyai harga jual dan permintaan yang tinggi. Hal ini jelas berdampak langsung terhadap kehidupan masyarakat Kapuas Hulu sebagai daerah pemasok serbuk kratom terbesar.

Kecamatan Putussibau Utara terdiri atas 19 desa, dan Desa Banua Tengah, Desa Sungai Uluk Palin, dan Desa Hilir Kantor. Hasil identifikasi dan survei lapangan menunjukkan sebagian besar masyarakat kedua dusun tersebut berprofesi sebagai petani dan berkebun kelapa sawit. Beberapa mempunyai luasan perkebunan melebihi 10 hektar, dan sebagian besar merupakan petani kecil yang pendapatannya tidak tetap.
Hasil observasi dan karakterisasi lapang menemukan bahwa masyarakat tetap Kecamatan Putussibau Utara tergolong sebagai masyarakat tradisional, yang menjaga tradisi peninggalan nenek moyang dan adat istiadat yang berlaku. Masyarakat tradisional memiliki karakteristik untuk menjaga tata cara perilaku baik dalam hal aturan hubungan antar manusia (interaksi), maupun dengan alam sekitarnya yang mengutamakan keharmonisan, dan tingginya adaptasi sosial budaya serta religinya dengan mekanisme alam disekitarnya (Wiranto, 2004). Karakteristik yang dijelaskan oleh Wiranto tersebut sama seperti halnya ILO dalam Rosyani (2008: 46). Selama perjalanan waktu yang lama dengan akal yang dimilikinya, manusia semakin memiliki kemampuan menyempurnakan kebudayaan dan tata cara sosial yang dimilikinya. Setiap kali mereka berupaya menyempurnakan dirinya, maka akan menyebabkan perubahan kebudayaan dan tatanan sosialnya (Poerwanto, 2005).

Tiga yang dikemukakan sebagai alasan mendasar terjadinya perubahan kebudayaan dan interaksi, yaitu : (a) jarak komunikasi antar kelompok, pelaksanaan pembangunan, dan (c) kemajuan ilmu pengetahuan dan teknologi (Munandar dalam Muhammad, 2008). Perubahan kebudayaan disebabkan oleh munculnya penemuan baru (invention), 
difusi, akulturasi dan perubahan suatu lingkungan (Purwanto, 2005). Apabila sistem nilai budaya dan sosial mengalami perubahan, akan terjadi pula perubahan sikap mental, pola pikir, dan pola tingkah laku anggota masyarakat dalam berbagai aspek nilai kehidupan. Perubahan sistem nilai budaya dapat berakibat positif dan negatif. Dampak positif yaitu memperkaya nilai-nilai kehidupan yang sudah ada, mendorong kearah kemajuan, dan mensejahterakan kehidupan masyarakat, sedangkan dampak negatif yaitu merusak nilai kehidupan yang sudah ada, menghambat kemajuan, memperburuk sendi-sendi kehidupan, dan merugikan masyarakat sehingga terjadi krisis kemasyarakatan (Muhammad, 2008).

Perubahan mata pencaharian masyarakat petani asal Putussibau Utara menjadi petani dan pedagang kratom, berdampak besar terhadap meningkatnya nilai taraf hidup, kebudayaan, dan pola interaksi masyarakat. Peralihan sumber mata pencaharian ini menyebabkan timbulnya perubahan interaksi sosial maupun hubungan kerja antara satu dengan yang lain. Interaksi sosial yang terjadi antar pedagang berpengaruh terhadap sikap dan perilaku dalam kegiatan ekonomi. Hubungan kerja yang terjalin dalam kegiatan perdagangan Kratom juga lebih didominasi oleh hubungan yang bersifat persaingan dan konflik. Interaksi kerja ini menjadi suatu keharusan melalui komunikasi dan kontak yang menjadi syarat utama terjadinya interaksi sosial yang komplek. Komunikasi dan interaksi sosial membuat satu pedagang dengan pedagang yang lain dapat saling mempengaruhi, dan menghasilkan hubungan positif yaitu adanya kerja sama yang terjalin, maupun negatif berupa persaingan hingga konflik.

Hal inilah yang perlu diketahui, terkait semakin banyaknya petani dan pedagang kratom di Kecamatan Putussibau Utara akankah berdampak negatif terhadap bentukan pola interaksi masyarakat yang terjalin. Keberadaan informasi dan data yang kuat tentang dampak sosial dan interaksi masyarakat terdampak popularitas kratom dapat digunakan sebagai pijakan ilmiah dalam antisipasi kebijakan sosial pada pertanian dan perdagangan kratom dikemudian hari. Jika dilihat dari fenomena di atas yang menjelaskan bahwa telah terjadi peralihan sistem mata pencaharian hidup masyarakat Putussibau Utara. Hal ini menunjukkan bahwa telah terjadi peralihan salah satu unsur kebudayaan dalam kelompok masyarakat tersebut. Maka dari itu, dirasa perlu dilakukan penelitian dengan judul penelitian: "Peralihan Sistem Mata Pencaharian dan Pola Interaksi Masyarakat Petani Kratom Di Kecamatan 
Putussibau Utara, Kabupaten Kapuas Hulu, Kalimantan Barat”.

\section{METODE}

\section{Subjek dan Objek Penelitian}

Penelitian ini dilakukan di Kabupaten Kapuas Hulu, khususnya pada daerah Kecamatan Putussibau Utara. Kecamatan ini terdiri atas 18 Desa yang tersebar pada luasan daerah 139,3 km2. Obyek dalam penelitian ini berupa Desa Banua Tengah, Desa Sungai Uluk Palin, dan Desa Hilir Kantor. Ketiga desa tersebut memiliki kriteria yang memenuhi sebagai lokasi sampel, yaitu merupakan daerah dengan petani dan pedagang kratom terbesar di Kapuas Hulu, serta memiliki luasan areal penanaman kratom yang besar. Selain itu daerah sampel tersebut juga memiliki total populasi yang tinggi dibandingkan desadesa lainnya. Pada tahun 2018, jumlah penduduk Desa Banua Tengah, Sungai Uluk Palin, dan Hilir Kantor berturut-turut adalah 494, 642, dan 3.417 jiwa (BPS, 2018). Populasi penelitian yang digunakan berupa masyarakat sampel yang bermata pencaharian sebagai petani tanaman pangan (padi dan sayur-sayuran) dan perkebunan (sawit dan karet). Subyek yang menjadi sampel penelitian dari populasi tersebut adalah masyarakat petani yang dapat mencerminkan seluruh karakteristik populasi, dan telah beralih mata pencaharian dari petani tanaman pangan dan perkebunan menjadi petani kratom minimal 2 tahun. Pengambilan data dilakukan dengan menggunakan metode purposive sampling. Penelitian ini menggunakan subyek berupa empat orang responden per desa yang akan ditentukan dengan pertimbangan inklusi berupa petani kratom yang memiliki kebun, serta berprofesi sebagai petani kratom minimal 2 tahun. Adapun karakteristik masyarakat Putussibau Utara berdasarkan sistem mata pencaharian tersebut adalah sebagai berikut

a) Karakteristik masyarakat Kecamatan Putussibau Utara bercocok tanam menetap.

1) Bercocok tanam pada sebidang tanah yang dikelola berkesinambungan

2) Melakukan upaya pemeliharaan kesuburan tanah

3) Melakukan upaya pemeliharaan tanaman

4) Tanah/lahan untuk bercocok tanam merupakan milik seorang individu

5) Menempati tempat tinggal dan menetap

6) Bisa melakukan usaha lain di luar bercocok tanam untuk memenuhi kebutuhan 
b) Karakteristik

masyarakat

Kecamatan

Putussibau

Utara

bercocok tanam di ladang

1) Membuka hutan untuk melakukan bercocok tanam

2) Dalam proses penanaman tidak dilakukan pengolahan tanah

3) Ladang ditanami secara tidak berkesinambungan

4) Lahan tempat bercocok tanam berpindah-pindah

5) Tidak ada upaya pemeliharaan kesuburan tanah

6) Tidak dilakukan upaya pemeliharaan tanaman

7) Tempat tinggal berupa gubug dan tidak menetap tergantung pada ladang tempat bercocok tanam

8) Tanah/ladang belum menjadi milik seorang individu

\section{Pengumpulan Data}

Penelitian ini menggunakan teknik pengumpulan data sekaligus sebagai metode triagulasi sumber informasi data untuk pengujian kredibilitas data yang diperoleh yaitu sebagai berikut :

Wawancara

Wawancara dilakukan dalam recording data pada studi pendahuluan untuk menemukan masalah utama yang akan diteliti, serta pendalaman psikis dan kondisi responden yang mendalam. Jenis wawancara yang digunakan meliputi wawancara semi terstruktur, dengan kajian eksploratif dan interaktif.

\section{Observasi}

Observasi dilakukan dengan teknik recording data yang sistematis untuk membantu perolehan data yang mendasari pernyataan spesifik dari individu yang mencerminkan tingkah laku yang nantinya dapat dianalisis lanjut. Pelaksanaan observasi akan dilakukan dengan checklist yang meliputi kompetisi antar masyarakat, konflik sosial, toleransi, dan perubahan budaya.

\section{Dokumentasi}

Data dokumentasi yang digunakan dalam penelitian ini meliputi tulisan, gambar, atau karya monumental dari seseorang. Dokumentasi tulisan yang akan dikoleksi meliputi catatan harian, sejarah kehidupan, biografi, peraturan, dan kebijakan adat. Dokumentasi gambar meliputi foto, gambar hidup, sketsa, dan lainnya.

\section{Analisis Data}

Analisis data yang digunakan dalam penelitian ini adalah teknik analisis interaktif. Analisis yang dilakukan terdiri 
atas empat prosedur, yaitu pengumpulan data; reduksi data sebagai proses pemilihan, pemutusan perhatian, penyederhanaan, pengabstrakkan, dari informasi data kasar yang muncul; penyajian data dengan mengorganisir informasi sistematis dalam mempermudah peneliti; penarikan kesimpulan/verifikasi dengan mencari arti benda-benda, mencatat keteraturan, pola, penejlasan, konfigurasi yang mungkin terjadi, alur sebab-akibat, dan proporsi.

\section{HASIL DAN PEMBAHASAN}

\section{Gambaran Umum Masyarakat Putussibau Utara}

Masyarakat asli Kecamatan Putussibau Utara, Kabupaten Kapuas Hulu merupakan kelompok masyarakat tradisional yang sudah sering mendapatkan sentuhan program pemerintah untuk peningkatan taraf pendidikan, dan hidup demi menunjang kesejahterahan hidup yang layak. Kelompok masyarakat ini pun sudah mengalami akulturasi budaya. Hal ini dapat dilihat dari berbagai cara kehidupan mereka yang sudah dapat mirip sekali dengan cara hidup masyarakat yang hidup di kota besar. Hampir keseluruhan penduduk asli telah memeluk agama, dengan agama mayoritas adalah Kristen dan Katolik, kemudian Muslim, bahkan banyak dari kelompk masyarakat tersebut yang telah menikah dengan etnis lain seperti Jawa dan Melayu.
Penduduk asli Putussibau Utara dalam berinteraksi dengan masyarakat sekitar juga cukup baik. Mereka mau dan aktif dalam mengikuti kegiatan-kegaiatan yang diselenggarakan oleh warga desa lain dan pemerintah daerah, seperti pengajian yasin dan gotong royong, bahkan sudah banyak yang mau menyekolahkan anaknya ke luar daerah. Mereka juga sudah sangat terbuka dengan orang asing yang baru mereka kenal seperti peneliti misalnya. Sebagian besar masyarakat ini sudah mau menerima perubahan dan menginginkan perbaikan. Mereka sudah mau mendengarkan nasihat dan petunjuk dari orang lain khususnya pemerintah desa dan kabupaten dalam rangka meningkatkan kesejahterahan hidupnya.

\section{Peralihan Mata Pencaharian Hidup Masyarakat dan Kebijakan Pemerintah}

Berdasarkan peralihan mata pencaharian hidup masyarakat asli Putussibau Utara yang terjadi adalah mengkombinasikan lebih dari satu jenis matapencaharian hidup berbeda. Meskipun mereka sebagian besar telah beralih menjadi petani kratom, akan tetapi tetap mempertahankan matapencaharian hidup yang lama, seperti bertani dan berladang padi, sayuran, karet, dan kelapa sawit. Lahan yang mereka buka ditanami tidak hanya oleh tanaman kratom tetapi juga oleh 
beragam jenis tanaman-tanaman lain, seperti ubi, pisang, tebu. Kratom yang menjadi peluang matapencaharian baru lebih banyak dibudidayakan pada daerah aliran sungai Kapuas, dan Sungai yang berbatasan dengan Taman Nasional Betung Kerihun. Dasar inilah dapat disimpulkan bahwa masyarakat asli telah melakukan matapencaharian yang baru tetap melakukan pula matapencaharian yang terdahulu mereka lakukan sebelum melakukan budidaya kratom.

Pemerintah dalam upaya pembangunan dan peningkatan kesejahterahan hidup masyarakat setempat telah melakukan berbagai program yang direalisasikan dalam beberapa bentuk seperti sosialisasi, pelatihan kemandirian pangan, unit kewirausahaan, dan sebagainya. Selain itu, pelaksanaan program juga melalui kerja sama dengan lembaga lain seperti LSM dan perusahaan sekitar kawasan Kecamatan Putussibau Utara. Pada dasarnya kebijakan pemerintah yang diberlakukan terhadap masyarakat tersebut dalam rangka modernisasi untuk peningkatan kesejahterahan dan taraf hidup yang layak. Masuknya potensi kratom sebagai sumber matapencaharian baru, bertolak belakang dengan programprogram terdahulu yang dilakukan oleh pemerintah. Dengan kata lain, asimilasi kratom dan peluangnya sebagai sumber matapencaharian baru dan utama bagi masyarakat Putussibau Utara terjadi dengan sendirinya oleh inisiasi masyarakat.

Seiring berjalannya waktu, semakin banyak masyarakat Putussibau Utara yang membudidayakan kratom sebagai usaha utamanya. Uniknya sampai peneliti turun langsung ke masyarakat desa yang melakukan peralihan matapencaharian sebagai petani kratom, belum mengetahui jelasnya peruntukkan kratom itu untuk apa. Akan tetapi dari hari ke hari jumlah penduduk yang melakukan kegiatan usaha ini kian banyak, karena nilai jual tinggi, dan prosek pasar yang terus berkembang.

\section{Interaksi Dengan Warga Desa}

Tokoh masyarakat dan Kepala Desa dari Putussibau Utara menyatakan masyarakat pertama kali mengetahui budidaya kratom dari warga asli yang melakukan jual beli kratom ke pasar Internasional, karena memang desa inilah yang paling cocok kondisi lahan dan topografinya dalam pembudidayaan kratom. Pada saat perkembangan awalnya masih belum banyak masyarakat yang membudidayakan tanaman ini, walaupun sebenarnya tanaman ini telah lama tumbuh di Kapuas Hulu. Letak wilayah yang berdekatan membuat masyarakat desa dengan cepat mengetahui aktivitas dan adanya peluang sumber matapencaharian 
baru. Hal ini dipengaruhi oleh adanya interaksi antara masyarakat awal yang mengetahui budidaya dan potensi kratom dengan masyarakat asli yang belum pernah mendengar manfaat dan nilai jual kratom. Sedikit demi sedikit warga desa lainnya mulai terpengaruh untuk mencukupi kebutuhan hidup seperti segelintir warga desa awal yang lebih sejahtera sejak menjadi petani kratom.

Masyarakat awam memperhatikan bahwa petani kratom dari kehari mempunyai rumah yang makin bagus karena terus dibangun, makanan yang lebih beragam, adanya perubahan dari jenis kendaraan yang digunakan mulai dari sepeda motor bahkan mobil, serta alat komunikasi yang canggih berupa telepon seluler. Hal inilah yang awalnya menjadi stimulus penting terjadinya interaksi diantara warga desa awal dan perintis petani kratom di Putussibau Utara.

\section{Konflik Dalam Interaksi Antar Pedagang Kratom dan Masyarakat}

Penelitian ini menemukan bahwa budidaya kratom tidak menimbulkan konflik horizontal antara masyarakat dan petani kratom, melainkan kecenderungan konflik vertikal yang terjadi antara petani dengan pembeli (makelar/pengepul). Pola interaksi sosial yang baik terjadi antara petani kratom dan masyarakat umum dikarenakan adanya kepentingan bersama untuk mencapai tujuan dan kesejahterahan masyarakat. Interaksi sosial yang berujung pada kerja sama dan tidak adanya konflik dianggap sangat penting dalam pelaksanaan kehidupan masyarakat karena terciptanya situasi aman dan kondusif sehingga aktivitas perdagangan dapat berjalan dengan baik. Interaksi sosial merupakan hubungan sosial yang dinamis dan menyangkut hubungan antara orang perorangan, antara kelompok manusia, maupun perorangan dengan kelompok manusia (Soekanto, 2002). Bentuk-bentuk interaksi sosial dapat berupa kerja sama (cooperation), persaingan (competition), dan bahkan dapat juga berbentuk pertentangan public (Koentjaraningrat, 2009).

Hasil observasi yang dilakukan menemukan bahwa terdapat kesamaan tujuan dan identitas keperluan baik masyarakat awam maupun petani kratom. Konflik horizontal antar kelompok didasarkan pada adanya kesamaan dan perbedaan identitas baik dalam dimensi ekonomi, kultural, maupun politik (Ruman et. al., 2010). Pandangan masyarakat asli sangat positif dengan adanya budidaya kratom di Kecamatan Putussibau Utara karena dianggap tidak mengeksploitasi budaya lokal. Selain itu masyarakat berpandangan bahwa kratom merupakan 
kearifan lokal yang perlu dikembangkan karena merupakan tanaman lokal yang asli tumbuh di daerah Kapuas Hulu. Kemudahan dalam budidaya kratom dianggap masyarakat tidak selalu berdampak negatif terhadap kerusakan lingkungan maupun ekosistem lain di Kapuas Hulu.

Mayoritas mata pencaharian utama di Kabupaten Kapuas Hulu adalah bertani dan berkebun dan hampir sebagian besar ditopang oleh komoditas kratom. Ketimpangan antar petani terhadap pertanian kratom terjadi karena tidak adanya wewenang petani dalam menentukan harga jual kratom meskipun daya saing terhadap kualitas telah dilakukan oleh petani. Petani kratom banyak yang tidak mengetahui dasar penentuan harga jual kratom karena ditentukan oleh pembeli. Hasil observasi lapang yang dilakukan menemukan bahwa harga jual kratom ditentukan oleh makelar atau pengepul. Petani kratom tidak bisa menentukan sendiri harga kratom pada saat dilakukan transaksi jual beli. Harga jual kratom sebelum terdampak isu pelarangan adalah Rp 30.000,-/kg dan berubah menjadi $\mathrm{Rp}$ 20.000,- hingga Rp 23.000,-/kg remahan daun kering, setelah terdampak isu. Kondisi di lapangan menemukan kurangnya perhatian terhadap pengelolaan sumber daya manusia dan kesejahterahan petani kratom. Masyarakat pembudidaya kratom tidak mengetahui bahwa terdapat keberadaan lembaga/ organisasi yang menaungi kratom yaitu PERKRINDO (Persatuan Petani Kratom Indonesia). Hal ini berpengaruh terhadap ketiadaan kebijakan baku yang diketahui oleh petani mengenai system budidaya dan perdagangan kratom. Petani mengadakan pupuk sendiri, dengan system budidaya yang dilakukan dekat dengan pinggiran sungai dan Taman Nasional.

\section{Toleransi Antar Masyarat}

Hasil observasi mendalam yang dilakukan menemukan bahwa masyarakat Dayak dan Melayu yang berkembang di Putussibau Utara menunjukkan sikap toleransi yang seragam dalam hal pertanian kratom. Secara umum, berdasarkan data BPS, Kabupaten Kapuas Hulu dalam Angka (2019), memiliki jumlah populasi untuk tingkat pendidikan SLTP/ MTs/Sederajat dan SMU/SMA/Sederajat yaitu sekitar $40 \%$ (Tabel 1). 
Tabel 1. Jumlah Penduduk Angkatan Kerja Menurut Pendidikan Tertinggi yang Ditamatkan dan Jenis Kegiatan Selama Pengambilan Data

\begin{tabular}{|c|c|c|c|}
\hline \multirow{2}{*}{$\begin{array}{c}\text { Pendidikan Tertinggi yang } \\
\text { Ditamatkan }\end{array}$} & \multicolumn{3}{|c|}{ Angkatan Kerja } \\
\hline & Bekerja & $\begin{array}{c}\text { Pengangguran } \\
\text { Terbuka }\end{array}$ & Jumlah \\
\hline (1) & (2) & (3) & (4) \\
\hline$<=\mathrm{SD} / \mathrm{MI} /$ Sederajat & 73749 & 149 & 73898 \\
\hline SLTP/MTs/Sederajat & $29794 \square$ & 1856 & 31650 \\
\hline SMU/MA/Sederajat & 26284 & 1230 & 27514 \\
\hline SM Kejuruan & 4455 & 183 & 4638 \\
\hline Diploma 1/II/III/Akademi & 3280 & $\mathbf{o}$ & 3280 \\
\hline Universitas & 5145 & 184 & 5329 \\
\hline Jumlah & 142707 & 3602 & 146309 \\
\hline
\end{tabular}

Sumber: Kabupaten Kapuas Hulu Dalam Angka, 2020

Sikap toleransi terwujud dalam lingkungan masyarakat melalui proses pendidikan formal maupun non formal (Akhyar, et al., 2015). Namun, sikap toleransi yang terbentuk, tidak selalu dipengaruhi oleh tingkat pendidikan. Toleransi yang terbentuk dari budaya mampu membangun saling pengertian dan saling menghargai di tengah keragaman suku, agama, ras, dan bahasa (Poerwanto, 2005). Sikap toleransi memungkinkan terbentuknya sikap : menerma perbedaan, mengubah penyeragaman menjadi keragaman, mengakui hak orang lain, meghargai eksistensi orang lain, dan dukungan secara antusias terhadap perbedaan budaya dan keragaman ciptaan Tuhan Yang Maha Esa.

Terkait dengan pertanian yang dilaksanakan masyarakat Kapuas Hulu, sangat perlu adanya penekanan pada penghargaan hak-hak masyarakat dalam ketetapan berdasarkan hukum adat maupun berlandaskan hak dari pemerintah. Sebagai contoh kepemilikan tanah pribadi berdampingan dengan lahan adat, namun pemanfaatannya selalu berkesinambungan. Hal inilah yang menjadi salah satu bentukan sikap toleransi yang diwujudkan masyarakat Dayak dan Melayu yang berkembang di Kapuas Hulu. Kesuksesan dan kemapanan yang dialami oleh salah satu anggota keluarga, menjadi contoh bagi keluarga lainnya.

Perkembangan isu pertanian kratom yang masih dalam tahap penelitian dan pertimbangan pemerintah pusat berkaitan dengan status legalitas berpengaruh terhadap timbulnya sikap toleransi masyarakat berupa penyatuan pendapat. Pertanian kratom yang menjadi salah satu sumber pendapatan pokok menjadi dasar penyatuan persepsi dan pendapat masyarkat dalam perbincangan atau diskusi publik 
pada tingkatan desa maupun pemerintah. Karena adanya kesamaan kepentingan, terlihat bahwa sikap toleransi terbentuk dengan sendirinya. Persamaan pandangan menyatukan masyarakat dalam upaya mempertahankan pertanian kratom. Hal inilah yang menyebabkan pemerintah pusat dan daerah harus memiliki strategi sendiri dalam menyampaikan keputusan perihal status legalitas pertanian kratom, untuk menghindari adanya konflik yang dapat muncul di masyarakat.

\section{SIMPULAN}

Peralihan sistem matapecaharian hidup yang terjadi pada kelompok masyarakat petani kratom di Kecamatan Putussibau Utara merupakan salah satu bentuk perubahan sosial yang terjadi dalam sebuah komunitas. Perubahan sosial ini merupakan perubahan sosial dengan pola perubahan kombinasi. Hal ini dikarenakan masyarakat asli Putussibau Utara melakukan pertanian tanaman kratom tanpa meninggalkan sepenuhnya mata pencaharian sebelumnya yang dilakukan. Berdasarkan uraian teoritik dan temuan diketahui bahwa tidak terjadi konflik horizontal yang terjadi antar petani kratom di Kecamatan Putussibau Utara. Kecenderungan yang terjadi justru konflik vertikal antara kelompok petani kratom dengan pembeli dan pemerintah, yang erat hubungannya dengan rendahnya penetuan harga beli kratom dan regulasi jual beli yang semakin dibatasi. Penerapan kebijakan pelarangan kratom di Kecamatan Putussibau Utara dapat menimbulkan polemic baru, dimana masyarakat "sudah nyaman" untuk budidaya kratom, yang dianggap tanaman asli dan aman dikonsumsi.

\section{DAFTAR PUSTAKA}

Akhyar, Zainul, H. Matnuh, S. Patimah, 2015, Implementasi Toleransi Antar Umat Beragama Di Desa Kolam Kanan Kecamatan Barambai Kabupaten Barito Kuala, $J$. Pendidikan Kewarganegaraan. Vol 5 (9): $724-734$.

Kabupaten Kapuas Hulu Dalam Angka, 2019, BPS Kabupaten Kapuas Hulu.

Koentjaraningrat, 2009. Pengantar Ilmu Antropologi. Jakarta: Rineka Cipta.

Mitragyna speciosa. Germapalsm Resources Information Network (GRIN). Agricultural Research Network Service (ARS), USDA. Retrieved 2013-12-26.

Muhammad, A. 2008. Ilmu Sosial Budaya Dasar. Bandung: Citra Aditya Bakti.

Poerwanto, H. 2005. Kebudayaan dan Lingkungan dalam Perspektif Antropologi. Yogyakarta: Pustaka Pelajar.

Rosyani. 2008. Keberlanjutan Masyarakat Adat, Masyarakat Desa dan Perusahaan Perkebunan (Kajian Pemanfaatan Lahan dan Kehidupan Masyarakat Sekitar Perusahaan Perkebunan di Provinsi Jambi). 
Disertasi Jenjang Pendidikan Doktor Program Studi Ilmu Lingkungan Program Pascasarjana Universitas Indonesia.

Rumah, Y. S., Gea, A. A., 2010, Konflik Pertanian Antara Komunitas di Desa Watu Nggelek Kecamatan Komodo Kabupaten Manggarai, Flores, NTT Tahun 1996 - Sekarang, Humaniora, Vol.1(2), Bina Nusantara University.

Soekanto, S., 2010, Sosiologi Suatu Pengantar, Jakarta: Rajawali Press.

Warner, M.L., Kaufman, N.C., \& Grundmann, O. 2016. The pharmacology and toxicology of kratom: from traditional herb to drug of abuse. Int J Leg Med (Review). 130 (1): 127-38.

Wiranto, Indriyo, D., Syaifudin, A., Kartika SA. 2004. Berkaca di Cermin Retak Refleksi Konservasi dan Implikasi Bagi Pengelolaan Taman Nasional. Jakarta: FoReST Press. 